\title{
STRUKTUR KOMUNITAS DAN DISTRIBUSI TEMPORAL GASTROPODA DI DANAU SITU GINTUNG, TANGERANG SELATAN, BANTEN
}

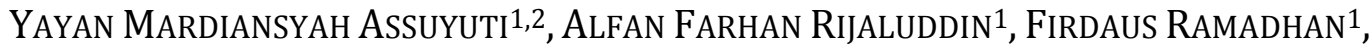 \\ REZA BAyU ZiKRILlaH ${ }^{1}$, DWI CAHYA KuSUMA ${ }^{3}$
}

\begin{abstract}
${ }^{1}$ Program Studi Biologi, Fakultas Sains dan Teknologi, Universitas Islam Negeri Syarif Hidayatullah Jakarta, Tangerang Selatan, Banten ${ }^{2}$ Laboratorium Ekologi, Pusat Laboratorium Terpadu, Universitas Islam Negeri Syarif Hidayatullah Jakarta, Tangerang Selatan, Banten ${ }^{3}$ Balai Riset Pemulihan Sumber Daya Ikan, Kementrian Kelautan dan Perikanan, Jatiluhur, Purwakarta, Jawa Barat
\end{abstract}

\section{A B S T RA C T}

The changes in the physicochemical of waters in the lake ecosystem caused by seasonal variation, anthropogenic and industrial wastes impact the gastropod community. This study aimed to determine the physicochemical parameter of waters, community structure and distribution of gastropod, and the correlation between those two in the dry and rainy seasons. We conducted this research in the lake of Situ Gintung located in Tangerang Selatan, Banten, Indonesia during the dry season (May to August 2015) and the rainy season (February to April 2016). Statistical analysis showed the physicochemical parameter of waters in both seasons has no different, while the gastropod showed a slight difference in occurrence based on the season, in which rainy season had the highest occurrence. Canonical Correspondence Analysis (CCA) suggested that gastropods occurrence were affected by the light intensity in the rainy season and the temperature in the dry season.

KEY WoRDS: Community Structure, Situ Gintung, Seasons, CCA

Penulis korespondensi: YAYAN MARDIANSYAH ASSUYUTI | email: ymar.assuyuti@uinjkt.ac.id

Dikirim: 17-06-2017 | Diterima: 03-08-2017

\section{PENDAH U L U A N}

Jumlah Gastropoda perairan darat di seluruh dunia kurang lebih adalah 4.000 spesies (Strong et al., 2008). Gastropoda selain memiliki fungsi penting secara ekologi (Strong et al., 2008) juga mempunyai peran lain yaitu sebagai indikator perubahan lingkungan (Zhou et al., 2008; Putri et al., 2017), sebagai sumber penyakit pada manusia (Strong et al., 2008), sebagai indikator tingkat toksikologi lingkungan (Pinel-Alloul et al., 1996), dan secara ekonomi sebagai sumber bahan pangan. Salah satu habitat Gastropoda perairan tawar adalah ekosistem danau yang secara umum dalam beberapa dekade terakhir setiap tahunnya mengalami gangguan kesimbangan ekologi yang diakibatkan aktivitas manusia (Duan et al., 2009; Strayer \& Dudgeon, 2010) berupa eksploitasi besar-besaran (Zhang \& Mei, 1996), dan perubahan iklim (O'Reilly et al., 2003). Hal ini baik secara langsung maupun tidak langsung berdampak pada fungsi ekosistem, kondisi habitat, kesimbangan rantai makanan, dan komunitas makrobentos (Woodward et al., 2010), di antaranya adalah Gastropoda (Lange et al., 2013).

Gastropoda di ekosistem danau dipengaruhi oleh parameter fisik-kimia perairan. Secara langsung atau tidak langsung, parameter tersebut dipengaruhi oleh perubahan iklim dan perubahan lahan di daratan sekitarnya, termasuk bahan kimia (Carpenter et al., 2011), fisik-kimia perairan, dan perubahan musim (Mola \& Gawad, 2014). Sebagai upaya konservasi, studi dampak perubahan fisik-kimia perairan terhadap Gastropoda perlu dilakukan, diantaranya adalah dengan mengetahui data keanekaragaman biota perairan (Strayer \& Dudgeon, 2010) dan faktor fisik-kimia perairan (Cai et al., 2011). Data tersebut dapat dijadikan sebagai salah satu dasar untuk pengelolaan (Cai et al., 2011) atau pembuatan kebijakan (Brown et al., 2009) untuk menjaga lingkungan dari kerusakan dan dominansi spesies tertentu (Lange et al., 2013).

Situ Gintung adalah salah satu danau di wilayah Kota Tangerang Selatan, Provinsi Banten, yang dikelilingi oleh perumahan, perkebunan, dan lokasi wisata. Pada tahun 2009, Situ Gintung pernah mengalami kerusakan tanggul, setelah renovasi terjadi perubahan jumlah inlet dan outlet, dari 2 outlet dan 2 inlet (Kristiana, 2003) menjadi 1 outlet dan 2 inlet hingga saat ini. Penelitian kualitas perairan di danau Situ Gintung telah dilakukan sebelumnya oleh Kristiana (2003), Widyana (2013), Bahri et al., (2015), dan Wardhana et al., 2017, akan tetapi penelitian Gastropoda secara spesifik belum pernah dilaporkan. Tujuan dari penelitian ini adalah untuk mengetahui parameter kimia-fisik perairan, struktur komunitas Gastropoda, dan hubungan antar kedua faktor tersebut pada musim kemarau dan musim hujan.

\section{MET O DE}

Penelitian ini dilakukan di perairan Situ Gintung, Kecamatan Ciputat Timur, Kota Tangerang Selatan, Banten (Gambar 1). Pengambilan sample Gastropoda dan pengukuran variabel fisik-kimia perairan dilakukan pada kurun waktu yang mewakili musim kemarau (Mei-Agustus 2015) dan musim hujan (Februari-April 2016). Pada periode tersebut, musim kemarau memiliki rata-rata temperatur udara $30-34{ }^{\circ} \mathrm{C}$ dan rerata presipitasi $0-87 \mathrm{~mm} /$ bulan, sedangkan pada musim hujan rerata temperatur udara diketahui $23-31{ }^{\circ} \mathrm{C}$ dan rerata presipitasi sebesar $0-236 \mathrm{~mm} /$ bulan (Accuweather, 2017). 


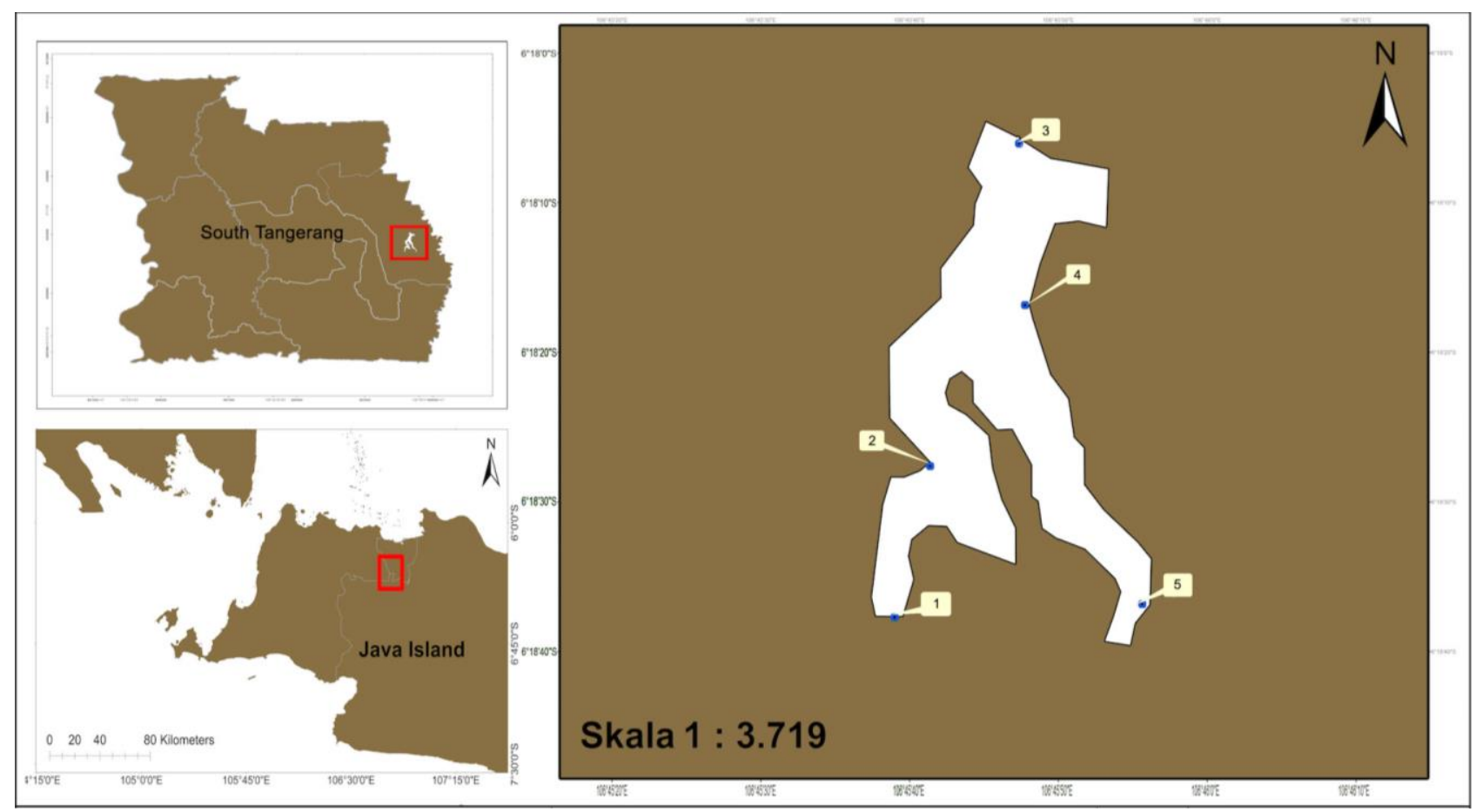

Gambar 1. Lokasi danau Situ Gintung (Wardhana et al., 2017)

Sampel Gastropoda dan data faktor fisik-kimia perairan dikoleksi 1 minggu sekali selama 3 minggu berturut-turut setiap bulan di lima stasiun. Stasiun pertama dan kelima merupakan inlet perairan, stasiun kedua dekat dengan daerah perumahan, stasiun keempat dekat dengan perkebunan, dan stasiun ketiga adalah outlet. Setiap stasiun diambil tiga kali pengambilan sampel Gastropoda sebagai ulangan dengan cara hand collecting (Marwoto et al., 2011) pada kuadrat $1 \mathrm{x} 1 \mathrm{~m}^{2}$. Parameter fisik-kimia perairan berupa temperatur, $\mathrm{pH}$, kecerahan, DO, TDS, EC, BOD 5 dan NPP diukur pada permukaan perairan. Sedangkan $\mathrm{BOD}_{5}$ yang diukur dengan metode Winkler (APHA, 2005; Jouanneau et al., 2014) hanya dilakukan 1 kali pengukuran dalam periode 3 minggu pengukuran parameter tersebut di atas untuk tiap stasiunnya. NPP diukur dengan merujuk pada APHA (2005). Sampel Gastropoda diawetkan dengan formalin 4\% dan dikoleksi di Laboratorium Ekologi, Pusat Laboratorium Terpadu UIN Syarif Hidayatullah Jakarta untuk selanjutnya diidentifikasi menggunakan referensi rujukan yaitu Thompson (2004), Marwoto et al. (2011) dan Quek et al. (2014).

Analisa data parameter fisik-kimia perairan dilakukan menggunakan MANOVA untuk mengetahui perbedaan antar musim. Data populasi Gastropoda dianalisis dengan menghitung densitas (indvidu $/ \mathrm{m}^{2}$ ), indeks keanekaragaman jenis Shannon-Wienner $\left(H^{\prime}\right)$ (Brower et al., 1990), indeks kemerataan jenis (E), dan indeks dominansi jenis (D). Tingkat keanekaragaman jenis dievaluasi dengan kriteria sebagai berikut $\mathrm{H}^{\prime} \leq 1$ menunjukkan tingkat keanekaragaman rendah, $1<\mathrm{H}^{\prime} \leq 3$ menunjukkan tingkat keanekaragaman sedang, dan $\mathrm{H}^{\prime}>3$ menunjukkan tingkat keanekaragaman tinggi. Densitas dan indeks Gastropoda diuji dengan Kruskal-Wallis, sedangkan Korelasi Spearman rank digunakan untuk mengetahui hubungan antar parameter lingkungan perairan pada tiap musim. Analisis statistik dilakukan menggunakan IBM SPSS versi 21. Hubungan Gastropoda dengan variabel fisik-kimia perairan dianalisis menggunakan Canonical Correspondence Analysis (CCA) (ter Braak \& Verdonschot, 1995).

\section{HASIL DAN PEMBAHASAN}

Data parameter perairan di Situ Gintung pada kedua musim ditunjukkan pada Tabel 1 . Hasil uji beda nyata parameter lingkungan antara musim hujan dengan musim kemarau diketahui tidak berbeda nyata (MANOVA, $p<0,05$ ). Musim hujan dan musim kemarau memiliki perbedaan pada parameter EC,

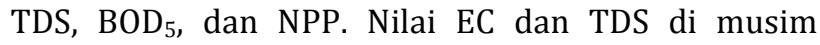
kemarau lebih tinggi dibandingkan dengan musim hujan, sebaliknya untuk nilai $\mathrm{BOD}_{5}$ dan NPP.

Tabel 1. Nilai rata-rata variabel fisik-kimia perairan danau Situ Gintung di musim kemarau dan musim hujan

\begin{tabular}{lrrrr}
\hline Fisik-kimia & \multicolumn{4}{c}{ Musim } \\
\cline { 2 - 5 } Perairan & Hujan & Stdev & Kemarau & Stdev \\
\hline$\left({ }^{\circ} \mathrm{C}\right)$ & 31,76 & 0,84 & 31,49 & 1,14 \\
Kecerahan $(\mathrm{cm})$ & 29,62 & 6,64 & 34,98 & 11,03 \\
DO $(\mathrm{mg} / \mathrm{L})$ & 6,88 & 0,64 & 7,13 & 0,55 \\
pH & 7,95 & 0,54 & 7,38 & 0,37 \\
EC $(\mu \mathrm{S} / \mathrm{cm})$ & 189,31 & 18,59 & 331,38 & 61,04 \\
TDS $(\mathrm{mg} / \mathrm{L})$ & 90,84 & 11,00 & 205,93 & 41,98 \\
BOD $(\mathrm{mg} / \mathrm{L})$ & 2,73 & 1,41 & 1,99 & 2,10 \\
NPP $\left(\mathrm{mgC} / \mathrm{m}^{3} /\right.$ hari $)$ & 590,18 & 246,47 & 445,25 & 204,75 \\
\hline
\end{tabular}

Hasil analisis korelasi Spearman antar parameter fisik-kimia perairan danau Situ Gintung disajikan pada Tabel 2. Temperatur perairan, pada kedua musim, memiliki korelasi positif dengan taraf sangat nyata terbanyak dibandingkan parameter lain. Pada musim hujan temperatur berkorelasi positif sangat nyata dengan DO, kecerahan, EC, dan NPP. Pada musim kemarau temperatur berkorelasi positif nyata dengan $\mathrm{pH}$, serta sangat nyata dengan DO dan $\mathrm{BOD}_{5}$. Temperatur, DO, dan kecerahan berkorelasi negatif dengan EC di musim hujan, sedangkan di musim kemarau hanya temperatur dan kecerahan yang 
berkorelasi negatif dengan EC. Temperatur di danau Situ Gintung memiliki kisaran yang sama dengan danau Maninjau Sumatra Barat (Merina et al., 2014) dan danau Sentani Papua (Surbakti, 2011) dengan kisaran 29-31 ${ }^{\circ} \mathrm{C}$. Nilai tersebut berbeda bila dibandingkan dengan danau Toba dengan rerata temperatur $25{ }^{\circ} \mathrm{C}$ (Barus, 2004), dan danau Matano Sulawesi Selatan pada akhir musim kemarau dengan nilai rerata temperature $27,8{ }^{\circ} \mathrm{C}$ (Crowe et al., 2008), dengan Situ Lembang yang berkisar antara $20-22,8{ }^{\circ} \mathrm{C}$ di musim kemarau dan awal musim hujan (Sulastri, 2011), serta dengan waduk Penjalin dengan kisaran temperatur $25-27{ }^{\circ} \mathrm{C}$ (Putri et al., 2017). Temperatur perairan danau Situ Gintung di musim hujan dan musim kemarau diduga dipengaruhi oleh temperatur atmosfir yang stabil dengan rata-rata $30-34{ }^{\circ} \mathrm{C}$ dan kecerahan $(r=0,700)$. Temperatur perairan danau mengalami fluktuasi karena pengaruh cahaya matahari, letak geografis (Lewis, 1987), suhu atmosfir (Wetzel, 2001), musim (Alam et al., 2001; Sulastri, 2011; Mola \& Gawad, 2014), ketinggian dari permukaan laut (Effendi, 2003), dan kedalaman air (Sarmento et al., 2006; Celik \& Ongun, 2007; Feresin et al., 2010; Sinaga et al., 2016).

Nilai pH perairan danau Situ Gintung memiliki kisaran yang sama dengan penelitian sebelumnya yaitu 6-9 (Nowrouzi \& Valavi, 2011; Celekli et al., 2014; Grabowska et al., 2014; Putri et al., 2017) dan berkorelasi positif dengan sebagian besar faktor fisikkimia perairan lain di musim kemarau (Tabel 2). Selain temperatur, pengaruh limbah antropogenik seperti fosfor, kalsium, dan alkalinitas (Brylinsky \& Mann, 1973), reaksi fotosintesis, nutrien (Morro et al., 2012), serta musim (Mola \& Gawad, 2014) dapat menyebabkan perubahan $\mathrm{pH}$ di perairan danau.

Nilai DO perairan Situ Gintung pada kedua musim memiliki kisaran yang sama dengan penelitian sebelumnya di danau Mandi India pada musim panas hingga musim dingin dengan nilai 3-13 mg.L ${ }^{-1}$ (Thakur et al., 2013), lebih rendah dari nilai DO di Situ Lembang pada musim kemarau yang mencapai 10 mg.L-1 (Sulastri, 2011). DO perairan Situ Gintung memiliki korelasi positif dengan temperatur dan $\mathrm{pH}$ di kedua musim (Table 2). Hal ini menunjukkan bahwa temperatur yang tinggi dapat menyebabkan kadar oksigen menurun dan $\mathrm{pH}$ meningkat. Kadar oksigen di perairan dipengaruhi oleh temperatur, aktifitas bakteri (Blumberg \& Toro, 1990), salinitas, tekanan atmosfer (Wetzel, 2001), blooming algae, $\mathrm{pH}$ (Xie et al., 2003), turbulensi air (Effendi, 2003), musim (Tian et al., 2013), dan kedalaman (Feresin et al., 2010; Sinaga et al., 2016).

Tabel 2. Matrik korelasi Spearman kondisi fisik-kimia perairan danau Situ Gintung pada musim hujan dan musim kemarau

\begin{tabular}{|c|c|c|c|c|c|c|c|c|c|c|c|}
\hline \multicolumn{12}{|c|}{ Musim Hujan } \\
\hline Parameter & ${ }^{\circ} \mathbf{C}$ & & pH & & DO & & Kecerahan & TDS & EC & BOD5 & NPP \\
\hline \multicolumn{12}{|l|}{${ }^{\circ} \mathbf{C}$} \\
\hline pH & 0,100 & & & & & & & & & & \\
\hline DO & 0,700 & $* *$ & 0,600 & $*$ & & & & & & & \\
\hline Kecerahan & 0,700 & $* *$ & 0,600 & $*$ & 1,000 & $* *$ & & & & & \\
\hline TDS & $-0,100$ & & $-0,300$ & & $-0,500$ & & $-0,500$ & & & & \\
\hline EC & $-0,800$ & $* *$ & 0,000 & & $-0,800$ & $* *$ & $-0,800 * *$ & 0,400 & & & \\
\hline BOD $_{5}$ & 0,200 & & $-0,500$ & & $-0,300$ & & $-0,300$ & $0,900 * *$ & 0,000 & & \\
\hline NPP & 0,700 & $* *$ & 0,100 & & 0,300 & & 0,300 & $0,600 *$ & $-0,300$ & $0,700^{* *}$ & \\
\hline \multicolumn{12}{|c|}{ Musim Kemarau } \\
\hline${ }^{\circ} \mathbf{C}$ & & & & & & & & & & & \\
\hline pH & 0,566 & * & & & & & & & & & \\
\hline DO & 0,720 & $* *$ & 0,548 & $*$ & & & & & & & \\
\hline Kecerahan & $-0,059$ & & $-0,295$ & & $-0,070$ & & & & & & \\
\hline TDS & 0,042 & & 0,252 & & 0,341 & & 0,014 & & & & \\
\hline EC & $-0,131$ & & 0,146 & & 0,186 & & $-0,034$ & $0,971 * *$ & & & \\
\hline BOD $_{5}$ & 0,757 & $* *$ & 0,601 & $*$ & 0,596 & $*$ & 0,071 & $0,552 *$ & 0,400 & & \\
\hline NPP & $-0,365$ & & 0,027 & & $-0,616$ & $*$ & 0,014 & 0,025 & 0,071 & $-0,082$ & \\
\hline
\end{tabular}

Tabel 3. Jumlah total sampel individu Gastropoda danau Situ Gintung

\begin{tabular}{|c|c|c|c|c|}
\hline \multirow{2}{*}{ Famili } & \multirow{2}{*}{ Species } & \multirow{2}{*}{ Kode } & \multicolumn{2}{|c|}{ Musim } \\
\hline & & & Hujan & Kemarau \\
\hline Ampullariidae & Pomacea canaliculata & PC/P. can & 472 & 319 \\
\hline Lymnaeidae & Lymnaea rubiginosa & LR/L. rub & 47 & 123 \\
\hline \multirow{3}{*}{ Planorbidae } & Gyraulus convexiusculus & GC/G. con & 13 & 4 \\
\hline & Indoplanorbis exustus & IE/I. exu & 164 & 61 \\
\hline & Physastra stagnalis & PS/P. sta & 9 & 1 \\
\hline \multirow[t]{4}{*}{ Thiaridae } & Melanoides plicaria & MP/M. pli & 7 & 1 \\
\hline & Melanoides tuberculata & MT/M. tub & 1 & 3 \\
\hline & Tarebia granifera & TG/T. gra & 18 & 1 \\
\hline & Thiara scabra & TS/T. sca & 3 & 4 \\
\hline \multirow[t]{2}{*}{ Viviparidae } & Filopaludina javanica & FJ/F. jav & 74 & 36 \\
\hline & Filopaludina sumatrensis & FS/F.sum & 18 & 18 \\
\hline Total & & & 826 & 571 \\
\hline
\end{tabular}


Nilai kecerahan di Situ Gunung memiliki kisaran yang sama dengan danau Gundolav (Sharma et al., 2010) dan danau Taihu (Cai et al., 2012) yaitu dibawah $1 \mathrm{~m}$, berbeda dengan Situ Lembang yang memiliki nilai kecerahan berkisar 1 meter (Sulastri, 2011). Kecerahan perairan Situ Gintung berkorelasi positif dengan temperatur, $\mathrm{pH}$, dan $\mathrm{DO}$ di musim hujan (Tabel 2). Menurut Hakanson (2006) kecerahan berkorelasi positif dengan kedalaman dan partikel terlarut di kolom perairan. Perbedaan kecerahan di ekosistem danau dipengaruhi oleh kekeruhan berupa padatan tersuspensi (Effendi, 2003), kepadatan populasi fitoplankton dan zooplankton, jumlah bahan organik terlarut (Torremorell et al., 2007), serta musim (Mola \& Gawad, 2014). Berdasarkan kategori kecerahan perairan (Peeters et al., 2009), danau Situ Gintung tergolong buruk atau memiliki kecerahan rendah.

Hasil pengukuran TDS di perairan danau Situ Gintung memiliki kisaran yang sama dengan penelitian sebelumnya di danau Mandi India pada musim panas sampai musim dingin dengan nilai 76296 mg.L-1 (Thakur et al., 2013). TDS di ekosistem perairan dipengaruhi musim, temperatur (Celik \& Ongun, 2007), dan pengaruh aktifitas manusia (Thakur et al., 2013). Nilai EC dan BOD 5 perairan Situ Gintung memiliki kisaran yang sama dengan penelitian sebelumnya yaitu sekitar $200-500 \mu \mathrm{S} \cdot \mathrm{cm}^{-1}$ untuk EC (Celik \& Ongun, 2007; Thakur et al., 2013; Grabowska et al., 2014), untuk BOD 5 setara dengan danau Greek (Kagalaou et al., 2003) dan danau Mandi (Thakur et al., 2013) yaitu sekitar 0-8 mg.L-1. Nilai EC berkorelasi positif dengan nilai TDS di musim kemarau namun berkorelasi negatif dengan nilai temperatur, D0, dan kecerahan di musim hujan. Nilai $\mathrm{BOD}_{5}$ di perairan Situ Gintung berkorelasi positif dengan temperatur, pH, DO, dan TDS di musim kemarau, dan hanya berkorelasi positif dengan TDS di musim hujan (Table 2). Nilai EC di ekosistem perairan dipengaruhi oleh temperatur air, $\mathrm{pH}$, kandungan nutrien, kandungan oksigen, percampuran air, kedalaman air, fotosintesis (Talling, 2009), dan musim (Mola \& Gawad, 2014), sedangkan $\mathrm{BOD}_{5}$ dipengaruhi oleh jumlah input nutrien organik ke dalam perairan (Nandini et al., 2005).

Nilai NPP perairan Situ Gintung di musim hujan lebih tinggi dibandingkan di musim kemarau. Hasil dari penelitian sebelumnya, nilai NPP perairan Situ Gintung lebih rendah dibandingkan dengan nilai NPP Waduk Cengklik (Pitoyo \& Wiryanto, 2002). Hasil analisis korelasi Spearman menunjukkan bahwa nilai NPP berkorelasi positif dengan nilai temperatur pada musim hujan (Tabel 2). Nilai NPP dipengaruhi oleh aktifitas pertambakan, kedalaman air (Pitoyo \& Wiryanto, 2002), kecerahan, dan bahan organik terlarut yang berasal dari daratan (Ask et al., 2009).

Jumlah total Gastropoda di perairan Situ Gitung pada kedua musim memiliki perbedaan (KruskallWallis, $p<0.05$ ). Gastropoda yang ditemukan di kedua musim memiliki jumlah 11 spesies dan 5 familia
(Viviparidae, Planorbidae, Lymnaeidae, Thiaridae dan Ampullariidae) (Tabel 3). Jumlah individu yang paling banyak ditemukan di musim hujan dan kemarau adalah $P$. canaliculata, sedangkan yang paling rendah adalah $M$. tuberculata, M. plicaria, P. stagnalis dan T. Granifera.

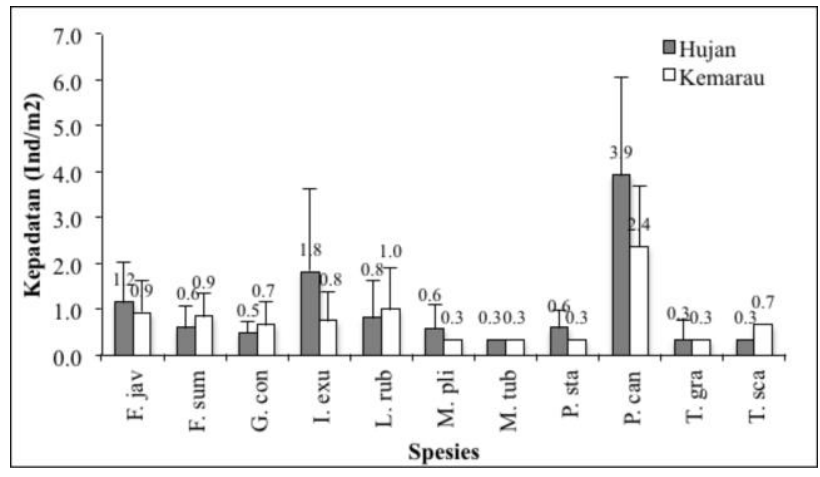

Gambar 2. Kepadatan spesies Gastropoda danau Situ Gintung di musim hujan dan musim kemarau

Kepadatan spesies Gastropoda danau Situ Gintung pada musim hujan dan musim kemarau tidak memiliki perbedaan (Kruskall-Wallis, $p>0,05$ ). Kepadatan tertinggi di kedua musim adalah spesies $P$. canaliculata sedangkan yang terendah adalah $M$. plicaria, M. tuberculata, P. stagnalis dan T. granifera di musim hujan dan spesies $M$. plicaria, M. tuberculata dan P. stagnalis di musim kemarau (Gambar 2). Ratarata kepadatan Gastropoda berdasarkan stasiun memiliki perbedaan antara musim hujan dengan musim kemarau (Kruskall-Wallis, $p<0,05$ ), dimana musim hujan memiliki kepadatan yang lebih tinggi dibandingkan dengan musim kemarau (Gambar 3). Kepadatan Gastropoda dipengaruhi oleh musim dan perubahan fisik-kimia perairan (Mola \& Gawad, 2014). Selain itu, kepadatan Gastropoda di ekosistem danau dipengaruhi oleh kandungan oksigen, limbah pabrik (Muli \& Mavuti, 2001), dan TSS (Putri et al., 2017). Menurut Tchakonté et al. (2014), dinamika populasi Gastropoda dipengaruhi musim dimana kelimpahan tertinggi terjadi pada musim hujan.

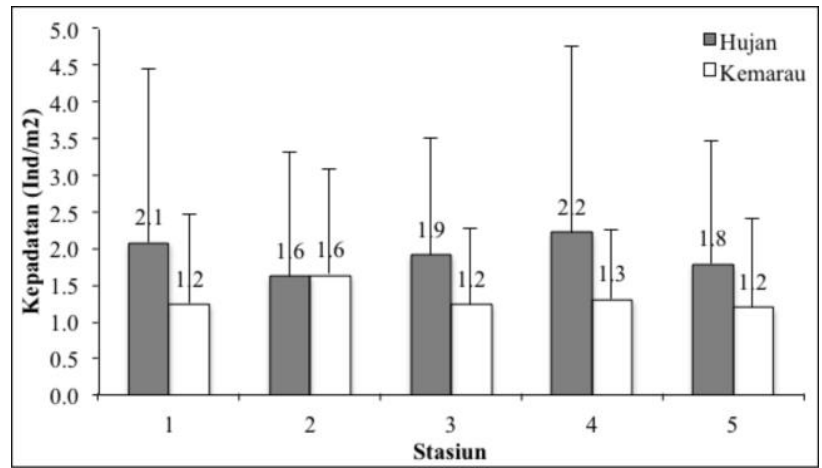

Gambar 3. Rata-rata kepadatan Gastropoda danau Situ Gintung berdasarkan stasiun di musim hujan dan musim kemarau

Gastropoda yang ditemukan di danau Situ Gintung pada penelitian ini lebih rendah dibandingkan dengan penelitian sebelumnya yang menemukan 13 spesies 
dan 6 familia (Adorable-Asis et al., 2016), namun lebih tinggi bila dibandingkan dengan waduk Penjalin dengan 7 spesies (Putri et al., 2017). Spesies P. canaliculata dari familia Ampullariidae memiliki jumlah individu dan kepadatan yang lebih tinggi di kedua musim dibandingkan dengan Thiaridae (Tabel 3; Gambar 2). Spesies ini tergolong invasive, sedangkan spesies lainnya yang ditemukan adalah non-invasive (GISD, 2017). Menurut Chiu et al. (2014), jenis $P$. canaliculata adalah spesies yang dapat hidup di perairan yang mengandung bahan pestisida dan dapat dijadikan sebagai bioindikator lingkungan. Spesies dari familia Thiaridae di danau Situ Gintung ditemukan lebih rendah dibandingkan dengan danau Sentani Papua yang memiliki jumlah 7 spesies (Surbakti, 2011), dan lebih tinggi dibandingkan dengan waduk Penjalin yang ditemukan 2 spesies (Putri et al., 2017). Keberadaan familia Thiaridae mengindikasikan kondisi kualitas perairan yang baik, karena ditemukan di daerah yang tidak ada pemukiman (Surbakti, 2011).

Populasi dan distribusi temporal M. tuberculata dan T. granifera ditemukan dalam jumlah yang rendah di kedua musim dibandingkan dengan spesies yang lain (Tabel 3; Gambar 2). Hasil yang berbeda dijumpai di Situ Gede Bogor, dimana dua spesies tersebut ditemukan melimpah di musim hujan dan musim kemarau (Priawandiputra et al., 2017). Distribusi temporal populasi T. granifera di ekosistem danau dipengaruhi oleh temperatur, $\mathrm{pH}$ (Miranda et al., 2011), zonasi (Vadeboncoeur et al., 2011), salinitas, umur, kedalaman air, sumber makanan (Miranda \& Perissinotto, 2012), karakteristik habitat danau (Lange et al., 2013), dan aktivitas manusia (Song et al., 2013).

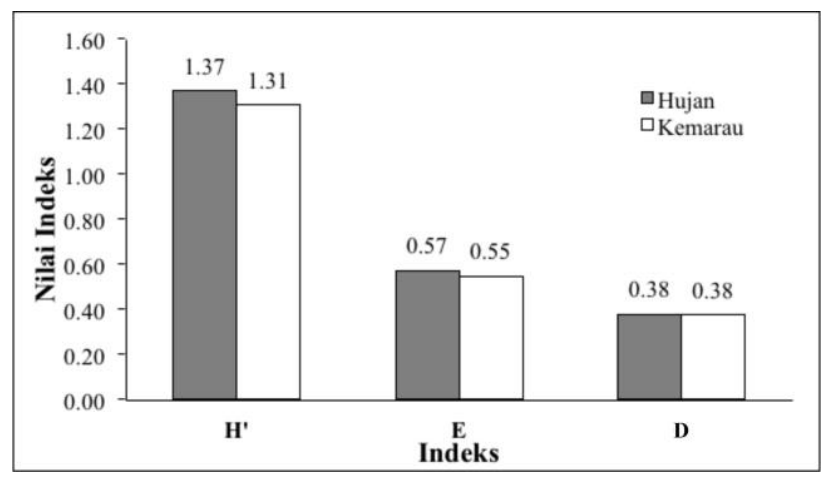

Gambar 4. Nilai indeks Keanekaragaman $\left(H^{\prime}\right)$,

Kemerataanan (E), dan Dominansi (D) Gastropoda di danau Situ Gintung pada musim hujan dan musim kemarau

Indeks ekologi Gastropoda di perairan danau Situ Gintung pada kedua musim ditunjukkan pada Gambar 4. Hasil penghitungan indeks keanekaragaman dan kemerataan pada kedua musim diketahui memiliki perbedaan (Kruskall-Wallis, $p<0.05$ ), sedangkan nilai indeks dominansi tidak memiliki perbedaan. Nilai indeks keanekaragaman menunjukkan bahwa Gastropoda perairan danau Situ Gintung termasuk dalam kategori sedang, dengan nilai indeks kemerataan jenis dan nilai indeks dominansi jenis menunjukkan bahwa jenis Gastropoda di perairan tersebut tersebar kurang merata dan ada jenis yang relatif dominan.

Indeks keanekaragaman $\left(H^{\prime}\right)$ Gastropoda di danau Situ Gintung memiliki kisaran yang sama dengan waduk Penjalin (Putri et al., 2017), namun lebih rendah bila dibandingkan dengan penelitian suatu danau di pulau Luzon Filipina dengan nilai 2,13 (Adorable-Asis et al., 2016). Dominansi Gastropoda di danau Situ Gintung lebih tinggi dibandingkan dengan waduk Penjalin (Putri et al., 2017). Menurut AdorableAsis et al. (2016), keanekaragaman jenis Gastropoda tergolong rendah dikarenakan degradasi habitat dan berlimpahnya spesies seperti $P$. canaliculata dan $T$. granifera. Selain itu, indeks keanekaragaman, kemerataan, dan dominansi di suatu ekosistem danau sangat dipengaruhi oleh variabel fisik-kimia perairan, musim, dan aktivitas antropogenik (Surbakti, 2011; Mola \& Gawad, 2014; Putri et al., 2017).

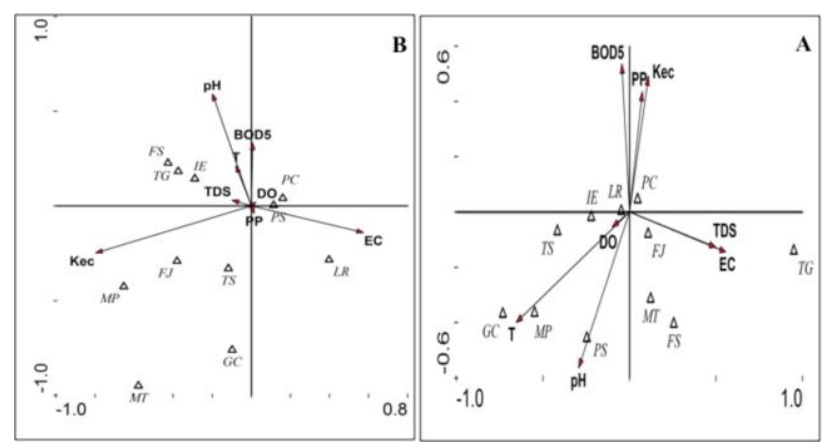

Gambar 5. Grafik plot Canonical Correspondence Analysis (CCA) komunitas Gastropoda dan parameter fisik-kimia perairan danau Situ Gintung pada musim hujan (A) dan musim kemarau (B)

Hasil analisis CCA hubungan komunitas Gastropoda dengan parameter lingkungan perairan danau Situ Gintung ditujukkan pada Gambar 5. Hasil analisis CCA menunjukkan bahwa pada musim hujan kecerahan perairan merupakan parameter yang paling berpengaruh terhadap kondisi Gastropoda ( $\mathrm{p}=$ $0,002)$, sedangkan temperatur adalah faktor yang paling berpengaruh pada musim kemarau $(p=0,02)$. Pengaruh temperatur dan kecerahan pada kedua musim diduga terkait dengan sumber pakan alami Gastropoda yaitu alga (perifiton) dan bahan organik. Selain itu, menurut Tchakonté et al. (2014), distribusi dan keberadaan Gastropoda pada musim hujan dan kemarau dipengaruhi oleh perbedaan temperatur pada tiap musim. Hasil penelitian Moslemi et al. (2012) menunjukan perbedaan jumlah Gastropoda pada lokasi yang tertutup kanopi dengan yang tidak tertutup kanopi. Jumlah alga dan produksi bahan organik diketahui lebih besar pada lokasi yang terbuka atau tidak tertutup kanopi, dimana cahaya matahari dapat menjangkau badan perairan dan akhirnya dapat meningkatkan produksi primer. Lebih lanjut, kecerahan dan kandungan oksigen dalam air dapat mempengaruhi reproduksi organisme yang hidup di dalamnya (Mantale \& Patil 2012). 
Pada Gambar 5, spesies P. canaliculata berada pada bagian tengah grafik plot CCA, baik pada musim hujan maupun musim kemarau. Hal ini menunjukkan bahwa $P$. canaliculata lebih toleran terhadap perubahan kondisi lingkungan yang ada di danau Situ Gintung. Spesies $P$. canaliculata merupakan salah satu jenis makrozoobentos invasif (Qiu \& Kwong, 2009) dan dapat bertahan hidup di lingkungan perairan yang terkontaminasi polutan biokimia (Chiu et al., 2014). Jenis I. exustus dan P. stagnalis juga terlihat ada pada bagian tengah grafik plot, hal ini menunjukkan bahwa jenis Gastropoda ini juga tahan terhadap perubahan kondisi lingkungan perairan danau Situ Gintung. Patut diduga bahwa jenis dari familia Planorbidae memiliki pigmen respirasi (Brown, 2001), sehingga dapat bertahan pada kondisi lingkungan yang sedikit oksigen. Hasil penelitian Tchakonté et al. (2014) menunjukkan bahwa spesies dari familia Planorbidae relatif tidak dipengaruhi oleh variabel kimia-fisik perairan.

Jenis Gastropoda dari familia Thiaridae dan Viviparidae terlihat mendekati variabel lingkungan utama yang mempengaruhi pertumbuhan alga seperti kecerahan, temperatur, $\mathrm{pH}$, dan EC. Sumber makanan seperti alga di ekosistem danau merupakan faktor yang mempengaruhi distribusi Gastropoda. Makanan utama dari T. granifera adalah alga yang tumbuh pada substrat, berbagai macam mikroorganisme dan partikel-partikel kecil materi organik (Harfouche \& Jung, 2014). Spesies dari famili Viviparidae diketahui juga memakan alga, diatom, perifiton, detritivor, dan makrofita (Brown, 2001).

Temperatur di musim kemarau diketahui mempengaruhi Gastropoda di danau Situ Gintung, sesuai dengan hasil penelitian sebelumnya yang menunjukkan bahwa variabel temperatur dapat mempengaruhi populasi Gastropoda (Tchakonté et al., 2014). Lebih lanjut diketahui bahwa temperatur mempengaruhi populasi Gastropoda yang belum dewasa. Temperatur perairan yang lebih dari $30^{\circ} \mathrm{C}$ dapat menyebabkan jumlah Gastropoda menurun dibandingkan dengan temperatur kurang dari $30^{\circ} \mathrm{C}$. Sebagai tambahan menurut Song et al., (2013), nilai $\mathrm{pH}$ sedimen dan temperatur perairan juga mempengaruhi keberadan Gastropoda. Selain itu, penutupan oleh vegetasi air dan eutrofikasi dapat mempengaruhi keberadaan Gastropoda di ekosistem danau (Marie et al., 2015).

\section{KESIMPULAN DAN SARAN}

Parameter lingkungan diketahui tidak berbeda nyata antara musim hujan dengan musim kemarau. Temperatur perairan, pada kedua musim, memiliki korelasi positif antar parameter dengan taraf sangat nyata terbanyak dibandingkan parameter lain. Gastropoda pada kedua musim ditemukan berjumlah 11 spesies dari 5 familia (Viviparidae, Planorbidae, Lymnaeidae, Thiaridae dan Ampullariidae). Jumlah total Gastropoda di perairan Situ Gitung pada kedua musim diketahui memiliki perbedaan sedangkan kepadatan spesies pada musim hujan dan musim kemarau tidak memiliki perbedaan. Rerata kepadatan Gastropoda berdasarkan stasiun diketahui memiliki perbedaan antara musim hujan dengan musim kemarau, dimana musim hujan memiliki kepadatan yang lebih tinggi dibandingkan dengan musim kemarau. Hasil analisis CCA menunjukkan bahwa pada musim hujan kecerahan perairan merupakan parameter yang paling berpengaruh terhadap kondisi Gastropoda ( $p=0,002)$, sedangkan temperatur adalah faktor yang paling berpengaruh pada musim kemarau $(\mathrm{p}=0,02)$.

Ditemukan jenis Gastropoda invasive yang keberadaanya tidak terlalu dipengaruhi oleh musim yaitu $P$. canaliculata. Spesies invasive tersebut dapat mengancam kelestarian Gastropoda lokal danau Indonesia seperti $F$. javanica yang ada di danau Situ Gintung. Sehingga perlu dilakukan upaya konservasi, seperti pemantauan dan pengelolan untuk menjaga kualitas air (Lysne et al. 2008), di danau Situ Gintung agar tidak terjadi dominansi spesies Gastropoda invasive.

\section{DAFT AR REFERENSI}

Adorable-Asis AGA, Cauyan GA, Pagulayan RC, Magbanua FS, Papa RDS. 2016. The macro-gastropod communities of aquacultureintensive lakes in the Philippines. Molluscan Res. 36:223-230.

Alam MGM, Jahan N, Thalib L, Wei B, Maekawa T. 2001. Effects of environmental factors on the seasonally change of phytoplankton populations in a closed freshwater pond. Environ Int. 27:363-371.

APHA. 2005. Standard methods for the examination of water and wastewater. 21st Edition. USA.

Ask J, Karlsson J, Persson L, Ask P, Byström P, Jansson M. 2009. Terrestrial organic matter and light penetration: Effects on bacterial and primary production in lakes. Limnol Oceanogr. 54(6): 2034-2040.

Bahri S, Ramadhan F, Reihannisa I. 2015. Kualitas perairan Situ Gintung Tangerang Selatan. Biogenesis. 3:16-22.

Barus TA. 2004. Faktor-faktor lingkungan abiotik dan keanekaragaman plankton sebagai indikator kualitas perairan danau Toba. Jurnal Manusia dan Lingkungan. 11(2):64-72.

Blumberg AF, DMD Toro. 1990. Effects of climate warming on dissolved oxygen concentrations in lake Erie. T Am Fis Soc. 119: 210-223.

Brown KM. 2001. Mollusca: Gastropoda. In: Thorp JH, Covic AP, editors. Ecology and classification of North American freshwater invertebrates.. New York: Academic Press. p 297325.

Brown LE, Céréghino R, Compin A. 2009. Endemic freshwater invertebrates from southern France: diversity, distribution and conservation implications. Biol Conserv. 142:2613-2619.

Brower JE, Zar JH, von Ende CN. 1990. Field and laboratory methods for general ecology. 3rd ed. USA: Wm. C. Brown Publisher. 221 p.

Brylinsky M, Mann KH. 1973. An analysis of factors governing productivity in lakes and reservoirs. Limnol Oceanogr. 18:1-14.

Cai Y, Gong Z, Qin B. 2011. Influences of habitat type and environmental variables on benthic macroinvertebrate communities in a large shallow subtropical lake (Lake Taihu, China). Ann. Limnol. - Int. J. Lim. 47:85-95.

Cai Y, Gong Z, Qin B. 2012. Benthic macroinvertebrate community structure in Lake Taihu, China: effects of trophic status, windinduced disturbance and habitat complexity. J Great Lakes Res. 38:39-48.

Carpenter SR, Stanley EH, Vander Zanden MJ. 2011. State of the world's freshwater ecosystems: physical, chemical, and biological changes. Annu. Rev. Environ. Resour. 36:75-99. 
Celekli A, Öztürk B, Kapi M. 2014. Relationship between phytoplankton composition and environmental variables in an artificial pond. Algal Research. 5:37-41.

Celik K, Ongun T. 2007. The relationships between certain physical and chemical variables and the seasonal dynamics of phytoplankton assemblages of two inlets of a shallow hypertrophic lake with different nutrient inputs. Environ Monit Assess. 124:321-330.

Chiu YW, Wu JP, Hsieh TC, Liang SH, Chen CM, Huang DJ. 2014. Alterations of biochemical indicators in hepatopancreas of the golden apple snail, Pomacea canaliculata, from paddy fields in Taiwan. J Environ Biol. 35(4):667-673.

Crowe SA, O’Neill AH, Katsey S, Hehanussa P, Haffner GD, Sundby B, Mucci A, Fowle DA. 2008. The biogeochemistry of tropical lakes: a case study from lake Matano, Indonesia. Limnol Oceanogr. 53:319-331.

Duan H, Ma R, Xu X, Kong F, Zhang S, Kong W, Hao J, Shang L. 2009. Two-decade reconstruction of algal blooms in China's lake Taihu. Environ Sci Technol. 43:3522-3528.

Effendi H. 2003. Telaah kualitas air bagi pengelolaan sumber daya dan lingkungan perairan. Yogyakarta, Indonesia: Kanisius. 249 p.

Feresin EG, Arcifa MS, da Silva LHS, Esguícero ALH. 2010. Primary productivity of the phytoplankton in a tropical Brazilian shallow lake: experiments in the lake and in mesocosms. Acta Limnologica Brasiliensia. 22(4):384-396.

Grabowska M, Glińska-Lewczuk K, Obolewski K, Burandt P, Kobus S, Dunalska J, Kujawa R, Goździejewska A, Skrzypczak A. 2014. Effects of hydrological and physicochemical factors on phytoplankton communities in floodplain lakes. Pol J Environ Stud. 23:713-725.

Global Invasive Species Database (GISD). 2017. Available from http://www.iucngisd.org/gisd/search.php on 25-01-2017.

Hakanson L. 2006. The relationship between salinity, suspended particulate matter and water clarity in aquatic systems. Ecol Res. 21:75-90.

Harfouche, CD, Jung D. 2014. The effect of sedimentation levels on Tarebia granifera in freshwater lagoons in Punta Cana, Dominican Republic. Consilience: The Journal of Sustainable Development. 11(1):132-152.

Jouanneau S, Recoules L, Durand MJ, Boukabache A, Picot V, Primault Y, Lakel A, Sengelin M, Barillon B, Thouand G. 2014. Methods for assessing biochemical oxygen demand (BOD): a review. Water Res. 49:62-82.

Kagalou I, Petridis D, Tsimarakis G. 2003. Seasonal variation of water quality parameters and plankton in a shallow Greek Lake. Journal of Freshwater Ecology. 18:199-206.

Kristiana D. 2003. Kualitas perairan Situ Gintung di Kabupaten Tangerang, Banten [Skripsi]. IPBBogor.

Lange CN, Kristensen TK, Madsen H. 2013. Gastropod diversity, distribution and abundance in habitats with and without anthropogenic disturbances in Lake Victoria, Kenya. Afr J Aquat Sci. 38(3):295-304.

Lewis WM. 1987. Tropical limnology. Annu Rev Ecol Syst. 18:159184.

Lysne SJ, Perez KE, Brown KM, Minton RL, Sides JD. 2008. A review of freshwater gastropod conservation: challenges and opportunities. J N Am Benthol Soc. 27(2):463-470.

Mantale A, Patil M. 2012. The effect of water quality on oviposition in freshwater pulmonate snail Indoplanorbis exustus. International Journal of Innovations in Bio-Sciences. 2(4):217220.

Marie MAS, El-Deeb FAA, Hasheesh WS, Mohamed RA, Sayed SSM. 2015. Impact of seasonal water quality and trophic levels on the distribution of various freshwater snails in four Egyptian Governorates. Applied Ecology and Environmental Sciences. 3(4):117-126.

Marwoto RM, Isnaningsih NR, Mujiono N, Heryanto, Alfiah, Riena. 2011. Keong air tawar Pulau Jawa (Moluska, Gastropoda). Bogor: Pusat Penelitian Biologi LIPI.

Merina G, Afrizal S, Izmiarti. 2014. Komposisi dan struktur komunitas fitoplankton di danau Maninjau Sumatera Barat. Jurnal Biologi Universitas Andalas. 3:267-274.

Miranda NAF, Perissinotto R. 2012. Stable isotope evidence for dietary overlap between alien and native gastropods in coastal lakes of northern KwaZulu-Natal, South Africa. PLoS ONE. 7(2): e31897.

Miranda NAF, Perissinotto R, Appleton CC. 2011. Population structure of an invasive parthenogenetic gastropod in coastal lakes and estuaries of Northern KwaZulu-Natal, South Africa. PLoS ONE. 6(8): e24337.

Mola HRA, Gawad SSA. 2014. Spatio-temporal variations of macrobenthic fauna in Lake Nasser khors, Egypt. Egyptian Journal of Aquatic Research. 40:415-423.

Morro CA, Niell GM, Taberner AM. 2012. Phytoplankton as bioindicator for waste stabilization ponds. J Environ Manage. 95:S71-S76.

Moslemi JM, Snider SB, MacNeill K, Gilliam JF \& Flecker AS. 2012. Impacts of an invasive snail (Tarebia granifera) on nutrient cycling in tropical streams: The role of Riparian deforestation in Trinidad, West Indies. PLoS ONE. 7(6): e38806.

Muli JR, Mavuti KM. 2001. The benthic macrofauna community of Kenyan waters of Lake Victoria. Hydrobiologia. 458: 83-90.

Nandini S, Ramírez-García P, Sarma SSS. 2005. Seasonal variations in the species diversity of planktonic rotifers in lake Xochimilco, Mexico. J Freshwater Ecol. 20:287-294.

Nowrouzi S, Valavi H. 2011. Effects of environmental factors on phytoplankton abundance and diversity in Kaftar Lake. Journal of Fisheries and Aquatic Science. 6:130-140.

O'Reilly CM, Alin SR, Plisnier PD, Cohen AS, McKee BA. 2003. Climate change decreases aquatic ecosystem productivity of Lake Tanganyika, Africa. Nature. 424:766-768.

Peeters ETHM, Franken RJM, Jeppesen E, Moss B, Becares E, Hansson LA, Romo S, Kairesalo T, Gross EM, van Donk E, Noges T, Irvine K, Kornijow R, Scheffer M. 2009. Assessing ecological quality of shallow lakes: Does knowledge of transparency suffice?. Basic Appl Ecol. 10:89-96.

Pinel-Alloul B, Méthot G, Lapierre L, Willsie A. 1996. Macroinvertebrate community as a biological indicator of ecological and toxicological factors in lake Saint-François (Québec). Environ Pollut. 91:65-87.

Pitoyo A, Wiryanto. 2002. Produktifitas primer perairan Waduk Cengklik Boyolali. Biodiversitas. 3(1):189-195.

Priawandiputra W, Nasution DJ, Prawasti TS. 2017. Comparison of Freshwater Mollusc Assemblages between Dry and Rainy Season in Situ Gede System, Bogor, Indonesia. IOP Conf. Series: Earth and Environmental Science. 58:1-9.

Putri RJW, Carmudi, Pulungsari AE. 2017. Kualitas air waduk Penjalin berdasarkan struktur komunitas makrobenthos. Scripta Biologica. 4(1):69-73.

Qiu JW, Kwong KL. 2009. Effects of macrophytes on feeding and lifehistory traits of the invasive apple snail Pomacea canaliculata. Freshwater Biol. 54:1720-1730.

Quek A, Tan LY, Wang LK, Clews E. 2014. A guide freshwater fauna of ponds in Singapore. Tropical Marine Sciences Institute, National University of Singapore. Singapore.

Sarmento H, Isumbisho M, Descy JP. 2006. Phytoplankton ecology of lake Kivu (eastern Africa). J Plankton Res. 28:815-829.

Sharma A, Ranga MM, Sharma PC. 2010. Water quality status of historical Gundolav lake at Kishangarh as a primary data for sustainable management. South Asian Journal of Tourism and Heritage. 3:149-158.

Sinaga ELR, Muhtadi A, Bakti D. 2016. Profil suhu, oksigen terlarut, dan $\mathrm{pH}$ secara vertikal selama 24 jam di danau Kelapa Gading kabupaten Asahan Sumatera Utara. Omni-Akuatika. 12 (2):114124.

Song Z, Zhang J, Jiang X, Wang C, Xie Z. 2013. Population structure of an endemic gastropod in Chinese plateau lakes: evidence for population decline. Freshw Sci. 32(2):450-461.

Strayer DL, Dudgeon D. 2010. Freshwater biodiversity conservation: recent progress and future challenges. J N Am Benthol Soc. 29(1):344-358.

Strong EE, Gargominy O, Ponder WF, Bouchet P. 2008. Global diversity of gastropods (Gastropoda; Mollusca) in freshwater. Hydrobiologia. 595:149-166.

Sulastri. 2011. Perubahan temporal komposisi dan kelimpahan fitoplankton di Situ Lembang, Jawa Barat. Limnotek. 18:1-14.

Surbakti SB. 2011. Biologi dan ekologi Thiaridae (Moluska: Gastropoda) di danau Sentani Papua. Jurnal Biologi Papua. 3(2):59-66. 
Talling JF. 2009. Electrical conductance - a versatile guide in freshwater science. Freshwater Reviews. 2:65-78.

Tchakonté S, Ajeagah GA, Diomandé D, Camara AI, Ngassam P. 2014. Diversity, dynamic and ecology of freshwater snails related to environmental factors in urban and suburban streams in Douala-Cameroon (Central Africa). Aquat Ecol. 48:379-395.

ter Braak CJF, Verdonschot PFM . 1995. Canonical correspondence analysis and related multivariate methods in aquatic ecology. Aquatic Science. 57:255-289.

Thakur RK, Jindal R, Singh UB, Ahluwalia AS. 2013. Plankton diversity and water quality assessment of three freshwater lakes of Mandi (Himachal Pradesh, India) with special reference to planktonic indicators. Environ Monit Assess. 185:8355-8373.

Thompson FG. 2004. An identification manual for the freshwater snails of Florida. Gainesville: Museum of Natural History, University of Florida. 94 p. Available from htttp://www.flmnh.ufl.edu/natsci/malacology/flsnail/snails1.htm.

Tian C, Pei H, Hu W, Xie J. 2013. Phytoplankton variation and its relationship with the environmental factors in Nansi Lake, China. Environ Monit Assess. 185:8355-8373.

Torremorell A, Bustigorry J, Escaray R, Zagarese HE. 2007. Seasona dynamics of a large, shallow lake, laguna Chascomus: The role of light limitation and other physical variables. Limnologica. $37: 100-108$
Vadeboncoeur Y, McIntyre PB, Vander Zanden MJ. 2011. Borders of biodiversity: Life at the edge of the world's large lakes. BioScience. 61(7):526-537.

Wardhana HI, Nadila A, Mardiansyah, Ramadhan F \& Rijaluddin AF. 2017. Kualitas perairan pada bulan Ramadan di Situ Gintung, Tangerang Selatan, Banten. Jurnal Biodjati. 2:9-20.

Wetzel RG. 2001. Limnology: lake and river ecosystems. 3rd ed. San Diego, CA: Academic Press.

Widyana A. 2013. Kajian kualitas air Situ Gintung Kecamatan Ciputat Timur Tangerang Selatan [Skripsi]. Universitas Gadjah Mada-Yogyakarta.

Woodward G, Perkins DM, Brown LE. 2010. Climate change and freshwater ecosystems: impacts across multiple levels of organization. Philos T R Soc B. 365:2093-2106.

Xie LQ, Xie P, Tang HJ. 2003. Enhancement of dissolved phosphorus release from sediment to lake water by Microcystis blooms - an enclosure experiment in a hyper-eutrophic, subtropical Chinese lake. Environ Pollut. 122:391-399.

Zhang ZS, Mei ZP. 1996. Effects of human activities on the ecological changes of lakes in China. GeoJournal. 40:17-24.

Zhou Q, Zhang J, Fu J, Shi J, Jiang G. 2008. Biomonitoring: An appealing tool for assessment of metal pollution in the aquatic ecosystem. Anal Chim Acta. 606:135-150. 